\title{
Quality of life in liver transplant recipients and the influence of sociodemographic factors
}

\author{
Qualidade de vida em receptores de transplante de fígado \\ e a influência dos fatores sociodemográficos \\ Calidad de vida en receptores de trasplante de hígado y la \\ influencia de los factores sociodemográficos
}

Maria Isis Freire de Aguiar ${ }^{1}$, Violante Augusta Batista Braga ${ }^{1}$, José Huygens Parente Garcia², Clébia Azevedo de Lima ${ }^{3}$, Paulo César de Almeida ${ }^{4}$, Angela Maria Alves e Souza ${ }^{1}$, Isaura Letícia Tavares Palmeira Rolim ${ }^{5}$

How to cite this article:

Aguiar MIF, Braga VAB, Garcia JHP, Lima CA, Almeida PC, Souza AMA, et al. Quality of life in liver transplant recipients and the influence of sociodemographic factors. Rev Esc Enferm USP. 2016;50(3):411-418. DOI: http://dx.doi.org/10.1590/S0080-623420160000400006

${ }^{1}$ Universidade Federal do Ceará, Departamento de Enfermagem, Fortaleza, CE, Brazil.

${ }^{2}$ Universidade Federal do Ceará, Departamento de Cirurgia, Fortaleza, CE, Brazil.

${ }^{3}$ Universidade Federal do Ceará, Hospital Universitário Walter

Cantídio, Fortaleza, CE, Brazil.

${ }^{4}$ Universidade Estadual do Ceará, Fortaleza, CE, Brazil.

${ }^{5}$ Universidade Federal do Maranhão, Departamento de Enfermagem,

São Luís, MA, Brazil.

\begin{abstract}
Objective: To verify the influence of sociodemographic factors on the quality of life of patients after liver transplant. Method: Cross-sectional study with 150 patients who underwent liver transplant at a referral center. A sociodemographic instrument and the Liver Disease Quality of Life questionnaire were applied. The analysis of variance (ANOVA) was performed, as well as multiple comparisons by the Tukey test and GamesHowell tests when $p<0.05$. Results: Old age had influence on domains of symptoms of liver disease $(p=0.049)$, sleep $(p=0.023)$ and sexual function $(p=0.03)$. Men showed better significant mean values than women for the loneliness dimension $(p=0.037)$. Patients with higher educational level had higher values for the domain of stigma of liver disease $(p=0.014)$. There was interference of income in the domains of quality of social interaction $(p=0.033)$ and stigma of the disease $(p=0.046)$. Conclusion: In half of the quality of life domains, there was influence of some sociodemographic variable.
\end{abstract}

DESCRIPTORS

Liver Transplantation; Quality of Life; Health Evaluation; Health Profile. 


\section{INTRODUCTION}

Chronic liver disease brings changes in various organ systems, causing complications that affect the physical functioning and performance of patients. These include muscle cramps, weight loss, hepatic encephalopathy and ascites, and influence the feeling of well-being and satisfaction with life of patients, and negatively affect their quality of life (QOL) ${ }^{(1)}$. Faced with a degenerative and progressive disease, liver transplantation is recommended as an alternative therapy, allowing for the reversal of the terminal condition and improvement of these patients' quality of life ${ }^{(2)}$.

Over the past ten years, Brazil has experienced many advances in the sector, with the creation of new transplant centers and increased number of organ donors and transplants. In 2014, there were 64 active liver transplant teams registered with the National Transplant System, which performed 1,775 liver transplants, ranking second in number of solid organ transplants ${ }^{(3)}$.

Given this reality, studies on the quality of life of these patients became necessary to understand the disease impact on daily activities, and obtain information for comparing the different types of treatments and analyze the costs.

The increased concern about individuals' quality of life has led to the development and application of various generic and specific instruments. Generic instruments have certain limitations related to the identification of specific areas of diseases in certain health conditions. In turn, questionnaires focused on evaluation of specific diseases provide greater specificity and sensitivity in these patients than in the general population ${ }^{(4)}$.

Presently, specific questionnaires were designed to assess quality of life. They can be applied in specific populations with certain pathological conditions, and offer the advantage of a more detailed analysis of the impact and limitations caused by the disease in the lives of individuals, identifying particularities of the situation. The highlights among specific instruments for patients with liver disease are the Chronic Liver Disease Questionnaire (CLDQ), the Liver Disease Symptom Index (LDSI) and the Liver Disease Quality of Life (LDQOL) ${ }^{(5)}$.

During the literature search on studies assessing the quality of life in patients undergoing liver transplant, studies using specific instruments were scarce. In Brazil, was identified a single study with application of the Liver Disease Quality of Life (LDQOL) ${ }^{(6)}$, also used in the present study.

After transplantation, patients face a difficult routine that involves frequent medical follow-up, exams, risks of complications such as rejection and infection, the need for continuous immunosuppressive therapy and change of habits. Nevertheless, studies evaluating the recipients' quality of life have demonstrated the positive impact of liver transplant on quality of life $\mathrm{fe}^{(6-7)}$.

Thus, further studies are needed to deepen other determinants of health that can affect the quality of life of these people, including demographic and social factors. This will also provide subsidies for the planning of individualized and integrated care to liver transplant patients, and contribute to the knowledge production in the area.

Identifying patients at higher risk of decrease in the levels of quality of life and less satisfaction with the transplant results may help transplant teams (social workers, nurses and doctors) to develop early interventions and multidisciplinary approaches that potentially improve the outcomes of quality of life of these patients.

The aim of this study was to verify the influence of sociodemographic factors on the quality of life of patients after liver transplant.

\section{METHOD}

This is a cross-sectional, quantitative study performed in a national reference center for liver transplants in the city of Fortaleza, state of Ceará (CE).

The study population consisted of 425 patients who underwent liver transplant within the ten-year operating period of the unit, and aged above 18 years. The finite sample was calculated considering the confidence level of $95 \%$ and a sampling error of $4 \%$.

The following inclusion criteria were used to determine the sample: liver transplant recipients for at least six months, aged 18 years and over, coming from any state in the country, and regularly monitored at the transplant service. The sample included 150 patients.

The following recipients were excluded: transferred to other states, patients undergoing liver transplants for fulminant hepatitis or combined liver-kidney, as well as patients with hearing loss that could prevent conducting the interview.

The data collection period was from July/2012 until January/2013, when the sociodemographic instrument and the Liver Disease Quality of Life (LDQOL) questionnaire were applied to assess the quality of life (translated and validated version for the Brazilian population). The questionnaire comprises 17 questions directed to the signs and symptoms of the disease and the effect of treatment in everyday life, divided into 12 domains: symptoms of liver disease (17 items), effect of liver disease on daily activities (10 items), concentration (7 items), memory (6 items), sleep (5 items), loneliness (5 items), hope (4 items), quality of social interaction ( 5 items), health distress (4 items), stigma of liver disease (6 items), sexual function ( 3 items) and sexual problems $(3 \text { items })^{(8)}$.

Each question has a proper response system that evaluates the frequency, intensity, or agreement with statements on a Likert scale, with response scores ranging 0-6 points. The score of each item is converted to values of $0-100$, with subsequent calculation of mean scores for each domain. Higher scores represent higher quality of life.

The validation of the LDQOL original version was performed in adults with advanced chronic liver disease and candidates for liver transplant. Thus, the authors emphasized the instrument usefulness in studies evaluating the outcomes of quality of life of patients undergoing liver transplant or other medical and surgical interventions for the treatment of disease $e^{(9)}$.

Patients were invited to participate in the study in the days of return for post-operative follow-up visits in the transplant service. Data collection was conducted in the waiting room of the liver transplant clinic before and/or after the post-transplant follow-up appointments, taking 
due care to provide the necessary privacy. The LDQOL was applied to patients by the researcher after six months of transplant through an interview by preference of participants, since it could be self-administered.

Data analysis was performed using the Statistical Package for the Social Sciences (SPSS) version 18.0. In descriptive statistical analysis, categorical variables were represented by absolute (n) and relative (\%) frequency, and the score results of the LDQOL domains were expressed as mean and standard deviation (SD).

The analysis of variance (ANOVA) was used to check for significant differences of mean among groups according to sociodemographic variables, and when $p<0.05$, the Tukey and Games-Howell tests were used for multiple comparisons. The significance level adopted was 0.05 .

The study met the national and international standards of ethics in research with human beings. The project was approved by the Research Ethics Committee of the Hospital Universitário Walter Cantídio under number 041.06.12. Patients authorized their participation by signing the Informed Consent form.

\section{RESULTS}

Table 1 presents the sociodemographic profile of patients undergoing liver transplant.

Table 1 - Distribution of liver transplant recipients according to sociodemographic profile - Fortaleza, Ceará, Brazil, 2013.

\begin{tabular}{lccc}
\hline Characteristics & N & $\%$ & \\
Gender & & & \\
Male & 120 & 80.0 & \\
$\quad$ Female & 30 & 20.0 & \\
Age (years) & & & Mean \pm SD $^{*}$ \\
$18-39$ & 28 & 18.8 & $52.4 \pm 12.9$ \\
$40-59$ & 70 & 47.0 & \\
$60-76$ & 51 & 34.2 & \\
Race & & & \\
White & 45 & 30.0 & \\
Mixed race & 90 & 60.0 & \\
\hline
\end{tabular}

continued... ...continuation

\begin{tabular}{|c|c|c|c|}
\hline Characteristics & $\mathbf{N}$ & $\%$ & \\
\hline Black & 14 & 9.3 & \\
\hline Indigenous & 1 & 0.7 & \\
\hline \multicolumn{4}{|l|}{ Marital status } \\
\hline With partner & 102 & 68.0 & \\
\hline No partner & 48 & 32.0 & \\
\hline Years of study & & & Mean $\pm \mathrm{SD}^{*}$ \\
\hline None & 12 & 8.0 & $9.8 \pm 4.3$ \\
\hline $1-9$ & 48 & 32.0 & \\
\hline $10-12$ & 56 & 37.3 & \\
\hline $13-18$ & 34 & 22.7 & \\
\hline \multicolumn{4}{|l|}{ Occupation } \\
\hline Active & 58 & 38.7 & \\
\hline Retired & 53 & 35.3 & \\
\hline Pensioners, sick leave & 24 & 16.0 & \\
\hline None & 15 & 10.0 & \\
\hline \multicolumn{4}{|l|}{ Income (minimum wage) † } \\
\hline None & 15 & 10.0 & \\
\hline Up to 2 & 65 & 43.3 & \\
\hline 3 to 4 & 38 & 25.3 & \\
\hline 5 to 10 & 20 & 13.3 & \\
\hline 11 or more & 12 & 8.0 & \\
\hline
\end{tabular}

*SD: standard deviation. $†$ R $\$ 678.00,2013$, Brazil. Note: $(\mathrm{n}=150)$

Participants were predominantly male (80\%); the prevalent age group was $40-59$ years (47\%) with a mean of 52.4 years; the highest proportion was of mixed race participants (60\%), and most lived with a partner (68\%).

The educational level of participants revealed that the majority (37.3\%) had 10-12 years of study, followed by 1-9 years $(32 \%)$ and a mean of 9.8 years of study. Regarding occupation, $38.7 \%$ were professionally active, and among the inactive, $35.3 \%$ were retired. Most participants reported income of up to two minimum wages (43.3\%).

Table 2 shows the relationships between the mean values of LDQOL domains and sociodemographic characteristics.

Table 2 - Analysis of the influence of sociodemographic characteristics on domains of quality of life of the LDQOL scale after liver transplant - Fortaleza, Ceará, Brazil, 2013.

\begin{tabular}{|c|c|c|c|c|c|c|}
\hline \multirow{2}{*}{ Variables } & \multicolumn{6}{|c|}{ Domains } \\
\hline & Symptom & & Concentration & Memory & Interaction & Distress \\
\hline & \multicolumn{6}{|c|}{ Mean \pm SD } \\
\hline Age (years) & $p=0.049$ & $p=0.422$ & $p=0.336$ & $p=0.595$ & $\mathrm{p}=0.221$ & $\mathrm{p}=0.823$ \\
\hline $18-39$ & $95.2 \pm 6.4 \neq$ & $90.4 \pm 11.4$ & $95.1 \pm 12.2$ & $82.4 \pm 22.3$ & $83.8 \pm 9.1$ & $87.5 \pm 15.5$ \\
\hline $40-59$ & $94.8 \pm 7.1 \S$ & $92.5 \pm 10.1$ & $92.7 \pm 15.4$ & $83.8 \pm 21.2$ & $85.2 \pm 11.3$ & $88.8 \pm 15.4$ \\
\hline $60-76$ & $91.3 \pm 10.8$ & $89.9 \pm 12.9$ & $89.9 \pm 16.4$ & $79.6 \pm 24.0$ & $81.6 \pm 11.4$ & $87.1 \pm 15.7$ \\
\hline
\end{tabular}


...continuation

\begin{tabular}{|c|c|c|c|c|c|c|}
\hline \multirow{2}{*}{ Variables } & \multicolumn{6}{|c|}{ Domains } \\
\hline & \multicolumn{2}{|l|}{ Symptom } & \multirow[t]{2}{*}{ Concentration } & \multirow[t]{2}{*}{ Memory } & \multirow[t]{2}{*}{ Interaction } & \multirow[t]{2}{*}{ Distress } \\
\hline & & & & & & \\
\hline Gender & $\mathrm{p}=0.535$ & $\mathrm{p}=0.316$ & $\mathrm{p}=0.446$ & $p=0.964$ & $\mathrm{p}=0.538$ & $p=0.121$ \\
\hline Male & $93.7 \pm 9.1$ & $91.7 \pm 10.7$ & $91.7 \pm 15.9$ & $82.2 \pm 23.2$ & $84.1 \pm 10.8$ & $86.9 \pm 16.4$ \\
\hline \multirow[t]{2}{*}{ Female } & $92.5 \pm 8.1$ & $89.4 \pm 13.4$ & $94.0 \pm 12.2$ & $82.4 \pm 18.8$ & $82.7 \pm 12.2$ & $91.8 \pm 10.2$ \\
\hline & \multicolumn{6}{|c|}{ Mean \pm SD } \\
\hline Study (years) & $p=0.281$ & $\mathrm{p}=0.536$ & $\mathrm{p}=0.115$ & $p=0.710$ & $\mathrm{p}=0.951$ & $\mathrm{p}=0.741$ \\
\hline Up to 8 & $95.0 \pm 6.1$ & $90.8 \pm 10.7$ & $94.0 \pm 13.2$ & $84.1 \pm 19.8$ & $83.6 \pm 10.0$ & $88.9 \pm 13.4$ \\
\hline $9-12$ & $92.6 \pm 10.4$ & $90.5 \pm 12.5$ & $89.1 \pm 17.3$ & $80.7 \pm 23.0$ & $84.1 \pm 11.6$ & $86.7 \pm 16.4$ \\
\hline \multirow[t]{2}{*}{$13-18$} & $92.6 \pm 9.6$ & $93.1 \pm 10.0$ & $94.7 \pm 13.3$ & $81.9 \pm 25.1$ & $83.5 \pm 11.8$ & $88.2 \pm 16.9$ \\
\hline & \multicolumn{6}{|c|}{ Mean \pm SD } \\
\hline Occupation & $\mathrm{p}=0.176$ & $\mathrm{p}=0.300$ & $\mathrm{p}=0.153$ & $\mathrm{p}=0.177$ & $p=0.187$ & $\mathrm{p}=0.208$ \\
\hline Inactive & $92.7 \pm 9.7$ & $90.5 \pm 11.2$ & $90.7 \pm 16.4$ & $80.2 \pm 23.5$ & $82.9 \pm 11.2$ & $86.6 \pm 16.8$ \\
\hline \multirow[t]{2}{*}{ Active } & $94.7 \pm 7.4$ & $92.4 \pm 11.5$ & $94.4 \pm 12.9$ & $85.3 \pm 20.1$ & $85.3 \pm 10.6$ & $89.9 \pm 13.0$ \\
\hline & \multicolumn{6}{|c|}{ Mean \pm SD } \\
\hline Income (MW) & $\mathrm{p}=0.570$ & $\mathrm{p}=0.218$ & $\mathrm{p}=0.255$ & $\mathrm{p}=0.620$ & $\mathrm{p}=0.033$ & $\mathrm{p}=0.279$ \\
\hline$<2$ & $94.2 \pm 6.7$ & $89.6 \pm 11.5$ & $93.9 \pm 13.5$ & $82.7 \pm 22.1$ & $81.7 \pm 11.0 \ddagger$ & $87.6 \pm 14.3$ \\
\hline $2-3$ & $92.5 \pm 10.8$ & $91.8 \pm 11.8$ & $89.6 \pm 16.9$ & $80.3 \pm 22.2$ & $84.2 \pm 11.7$ & $86.2 \pm 17.3$ \\
\hline \multirow[t]{3}{*}{$4-7$} & $93.8 \pm 9.1$ & $93.9 \pm 9.6$ & $93.4 \pm 14.8$ & $85.2 \pm 23.4$ & $88.2 \pm 8.2$ & $92.0 \pm 13.7$ \\
\hline & \multicolumn{6}{|c|}{ Domains } \\
\hline & Sleep & & Hope & Stigma & Sexual function* & Sexual problems $\dagger$ \\
\hline & & & & $=\mathrm{SD}$ & & \\
\hline Age (years) & $p=0.023$ & $p=0.521$ & $p=0.203$ & $p=0.937$ & $p=0.03$ & $p=0.173$ \\
\hline $18-39$ & $82.2 \pm 16.0 \ddagger$ & $94.8 \pm 13.0$ & $93.4 \pm 10.0$ & $94.4 \pm 7.7$ & $91.3 \pm 8.6$ & $88.8 \pm 19.2$ \\
\hline $40-59$ & $79.7 \pm 16.6 \S$ & $97.2 \pm 10.0$ & $92.8 \pm 13.8$ & $93.4 \pm 12.7$ & $91.4 \pm 14.7 \S$ & $94.1 \pm 22.9$ \\
\hline \multirow[t]{2}{*}{$60-76$} & $72.6 \pm 17.3$ & $94.8 \pm 15.3$ & $88.1 \pm 20.0$ & $93.7 \pm 11.5$ & $81.0 \pm 23.4$ & $81.9 \pm 29.7$ \\
\hline & \multicolumn{6}{|c|}{ Mean \pm SD } \\
\hline Gender & $p=0.366$ & $p=0.037$ & $p=0.792$ & $p=0.934$ & $p=0.941$ & $p=0.661$ \\
\hline Male & $78.3 \pm 17.0$ & $97.0 \pm 11.4$ & $91.4 \pm 15.7$ & $93.7 \pm 10.9$ & $88.1 \pm 18.6$ & $89.5 \pm 25.1$ \\
\hline \multirow[t]{2}{*}{ Female } & $75.2 \pm 16.9$ & $91.7 \pm 16.0$ & $90.5 \pm 16.0$ & $93.5 \pm 13.4$ & $88.5 \pm 10.2$ & $83.3 \pm 27.8$ \\
\hline & \multicolumn{6}{|c|}{ Mean \pm SD } \\
\hline Study (years) & $p=0.315$ & $p=0.148$ & $p=0.772$ & $p=0.014$ & $p=0.526$ & $p=0.734$ \\
\hline Up to 8 & $79.4 \pm 15.0$ & $93.4 \pm 17.2$ & $91.9 \pm 13.6$ & $94.1 \pm 9.9 \ddagger$ & $86.2 \pm 21.7$ & $87.8 \pm 30.8$ \\
\hline $9-12$ & $78.3 \pm 15.7$ & $98.0 \pm 7.2$ & $90.1 \pm 15.3$ & $90.9 \pm 14.4 \S$ & $87.7 \pm 17.9$ & $89.4 \pm 26.8$ \\
\hline \multirow[t]{2}{*}{$13-18$} & $73.9 \pm 21.6$ & $96.2 \pm 11.0$ & $92.2 \pm 19.6$ & $98.0 \pm 4.5$ & $91.6 \pm 7.5$ & $87.9 \pm 18.6$ \\
\hline & \multicolumn{6}{|c|}{ Mean \pm SD } \\
\hline Occupation & $p=0.400$ & $p=0.800$ & $p=0.374$ & $p=0.515$ & $p=0.168$ & $p=0.554$ \\
\hline Inactive & $76.8 \pm 18.1$ & $95.7 \pm 13.8$ & $90.3 \pm 17.0$ & $93.2 \pm 10.2$ & $86.0 \pm 21.6$ & $84.5 \pm 31.7$ \\
\hline \multirow[t]{2}{*}{ Active } & $79.2 \pm 15.0$ & $96.3 \pm 10.4$ & $92.7 \pm 13.5$ & $94.4 \pm 13.3$ & $91.0 \pm 9.5$ & $93.5 \pm 13.5$ \\
\hline & \multicolumn{6}{|c|}{ Mean \pm SD } \\
\hline Income (MW) & $p=0.069$ & $p=0.257$ & $p=0.950$ & $p=0.046$ & $p=0.677$ & $p=0.017$ \\
\hline$<2$ & $78.8 \pm 16.4$ & $94.0 \pm 16.0$ & $91.6 \pm 13.8$ & $93.6 \pm 11.8 \neq$ & $88.6 \pm 16.5$ & $98.1 \pm 7.8$ \\
\hline $2-3$ & $74.1 \pm 17.1$ & $97.6 \pm 8.8$ & $90.7 \pm 15.4$ & $91.6 \pm 12.7 \S$ & $89.4 \pm 16.9$ & $87.5 \pm 26.3$ \\
\hline $4-7$ & $82.9 \pm 17.4$ & $97.1 \pm 9.4$ & $91.2 \pm 20.6$ & $98.2 \pm 5.0$ & $85.0 \pm 21.0$ & $66.6 \pm 39.0$ \\
\hline
\end{tabular}

${ }^{*} \mathrm{n}=94$ for the sexual function domain. $\uparrow \mathrm{n}=42$ for sexual problems. $\neq$ The first and third groups differed. $§$ The second and third groups differed.

Note: $(\mathrm{n}=150)$ 
With respect to age range, in the post-transplant period, patients aged 60 years and over had lower mean values in ten out of 12 LDQOL domains, compared to the other groups. Age had interference on results of symptoms of liver disease $(p=0.049)$, sleep $(p=0.023)$ and sexual function $(p=0.03)$. There was a significant difference between the age group 1839 years and 60-76 for the sleep domain (82.2 vs. 72.6, $\mathrm{p}=$ 0.042 ), and between the age range $40-59$ years and $60-76$ for sexual function (91.4 vs. 81.0; $\mathrm{p}=0.033$ ), with weaker difference $(p=0.060)$ between the last two in the domains of symptoms (94.8 vs. 91.3) and sleep (79.7 vs. 72.6).

As for participants' gender, there was balance between quality of life scores in most dimensions in the post-transplant period. Men presented higher significant values of QOL than women only for the loneliness domain (97.0 vs. 91.7, $\mathrm{p}=0.037$ ).

In the educational level analysis, for most domains there was no correlation between years of study and the quality of life of participants, with tendency to homogeneity of answers. There was difference between means only for the domain of stigma of the disease $(p=0.014)$, in which patients with 13 or more years of study showed higher values compared to less educated groups. Significant differences were found when comparing patients with up to eight years of study and 13-18 years (94.1 vs. 98.0, $\mathrm{p}=0.037$ ), and between groups with 9-13 years of study and $13-18$ years ( 90.9 vs $98.0 \mathrm{p}=0.002)$. There were no correlations between occupation and quality of life among the domains of LDQOL.

Regarding socioeconomic level, there was an association between income and quality of life of patients $(r=-0.129$; $p=0.001)$. The income has only affected the results of the domains of quality of social interaction $(p=0.033)$ and stigma of the disease $(p=0.046)$. In the multiple comparison analysis, patients with income of less than two minimum wages (MW) showed significant differences compared to those with between four to seven MW in the domains of quality of social interaction ( 81.7 vs. $88.2, p=0.008)$ and stigma (93.6 vs. 98.2, $\mathrm{p}=0.027$ ). The group with income of two to three MW differed from the group with income of more than four in MW in the stigma domain (91.6 vs. 98.2; $\mathrm{p}=0.003$ ).

\section{DISCUSSION}

Results of the demographic profile indicated that most study participants were male (80\%), and in the age range of $40-59$ years (47\%) and of 60 years or over (34.2\%), of mixed race $(60 \%)$ and lived with a partner $(68 \%)$. The percentage of males in this study was higher than that found in a similar Brazilian study $(67.3 \%)^{(8)}$, and closer to another study with candidates for liver transplant $(75.3 \%)^{(10)}$.

The analysis of the quality of life after transplant in relation to gender showed homogeneity in most scores of the LDQOL domains. This result can be explained by the difference in sample size.

The predominant age group was corroborated by a national study that examined the outcomes of transplantation of organs and tissues for a ten-year period, in which was observed that $49 \%$ of recipients were in the age range of
41-60 years ${ }^{(11)}$. However, an international study on sociodemographic differences in liver transplant services obtained higher percentage (79.3\%), considering the age range of 40-65 years $^{(12)}$.

In this study, there was an association between older age and decline of QOL scores $(p<0.05)$ in the domains of symptoms of liver disease, sleep and sexual function.

Data on race diverged from international studies, in which the white color predominated among liver transplant recipients in Pennsylvania, with $75.8 \%{ }^{(13)}$, and $95.6 \%$ in the Medical Center of the University of Pittsburgh ${ }^{(14)}$. These differences are related to regional variations in Brazil, considering that data were in proportion to the general population of the northeast and north of the country, accounting for $62.7 \%$ and $71.2 \%$ of mixed race, respectively. These were the places of higher origin of patients treated at the studied transplant center ${ }^{(15)}$.

Studies assessing the interference of demographic factors in the quality of life of patients referred to or undergoing transplant are scarce. A study conducted in Italy compared the quality of life before and after the transplant, and the demographic characteristics showed no significant differences between groups ${ }^{(16)}$. Another study performed in Cambridge (England) included patients in follow-up of 30 years post-transplant, and demonstrated that receptors of female gender and aged over 60 years were important factors associated with reduced physical functioning of the SF-36 scale ${ }^{(17)}$.

The marital status of participants was in line with findings of a study conducted in Belgium, in which most liver transplant patients were married, corresponding to $69.8 \%$ of the sample $\mathrm{e}^{(18)}$.

The patients' educational level was considered intermediate as $37.3 \%$ reported $10-12$ years of study, and $40 \%$ less than ten years of study. These data are in agreement with findings of a Brazilian study with pre- and post-transplant patients ${ }^{(19)}$, in which the majority had only primary school, and differed from data of two international studies in which $56.4 \%$ and $67.6 \%$ of liver transplant recipients had higher education ${ }^{(20-21)}$.

In the educational level variable was found a positive association between years of schooling and the quality of life level in the domain of stigma of the disease $(p=0.014)$, without significant differences for the other evaluated domains.

Several studies have addressed the influence of socioeconomic factors on health and quality of life of individuals. Thus, educational level is an important element when analyzing determinants of health of a population. Studies have shown the relationship between social conditions and health status. Among these, educational level has a direct influence on the health care of people, and may affect the development of self-care concepts in health, the environmental control, risk behaviors, prevention and lifestyles ${ }^{(22)}$.

A study examining the influence of socioeconomic and demographic factors in the quality of life of liver transplant recipients found that patients with higher educational level had significant scores in the SF-36 Physical Functioning domain ${ }^{(20)}$.

Regarding occupation, most (38.7\%) of the patients were professionally active, followed by the retired (35.3\%), 
corroborating a study in which employees and housewives corresponded to $37.3 \%{ }^{(23)}$.

With advancement of the chronic liver disease and its clinical manifestations, many patients are unable to work and need to quit their jobs either for medical reasons or to undergo the disease treatment in a transplant center outside their city. The return to work and social participation are important parameters in assessing the success of liver transplantation, considering all physical and social burden resulting from the disease and need for treatment.

In the present study was not identified a correlation between occupation and quality of life in the domains of the instrument used. The positive influence of labor activity in the lives of individuals was highlighted in the study that showed employed receivers had higher mean scores compared to unemployed/retired receivers in the following SF36 domains: physical functioning $(\mathrm{p}<0.001)$ physical role $(\mathrm{p}$ $=0.0012)$, vitality $(\mathrm{p}=0.01)$, social functioning $(\mathrm{p}=0.037)$, bodily pain $(p=0.14)$ and general health $(p=0.0972)^{(20)}$.

A study of 353 liver recipients in Finland using the 15D questionnaire instrument and evaluation of ability to work corroborates these data. The authors found that among 347 respondents, a third of all patients was employed during the study period, without differences depending on the etiology of indication. Among respondents of working age (20-65 years old), with $n=268,44 \%$ were active and these had better QOL than unemployed respondents of working age, with clinically important and statistically significant difference $(\mathrm{p}<0.0001)^{(24)}$.

The predominant income of the study participants was considered low because most received up to two minimum wages (43.3\%) and three to four (25.3\%), totaling 68.5\% of the sample. These data were similar to the findings of a retrospective study conducted in Italy with 221 liver transplant recipients, in which $80 \%$ of recipients had low socioeconomic status ${ }^{(25)}$.

Several authors have highlighted the influence of income on the health of individuals. People with higher income can enjoy better health status by allowing the use of income to buy goods and health services (medical consultations, medication, health insurance, exams, treatments), in addition to better housing and education conditions, and preventive care ${ }^{(26)}$.

In Hungary, a case-control study was conducted with 287 cases of chronic liver disease and 892 controls. It found that people with financial situation perceived as bad or very bad had $80 \%$ greater risk of disease development compared to people with good or very good financial situation ${ }^{(27)}$.

Similarly, a study with patients undergoing liver transplantation found that data related to graft failure, death and occurrence of complications had better outcome in patients of higher socioeconomic status. The mortality rates tripled in receptors with lower socioeconomic levels (18.6\%) compared to the high level (4.5\%). The Cox univariate and multivariate regression analysis revealed that the higher the educational level and socioeconomic status the lower the patient's risk of death ( $p=0.05, p=0.03$, respectively), and that socioeconomic status is a significant independent predictor of overall survival of these patients ${ }^{(25)}$.

Since this is a cross-sectional study, it was not possible to verify sociodemographic information before transplantation for comparison with the post-transplant period. Thus, the results point to the importance of future longitudinal studies to increase knowledge of the studied characteristics and the impact on these individuals' quality of life.

Furthermore, the generalization of results is limited to contexts similar to the Brazilian reality, considering the variation of demographic and social conditions in different countries.

\section{CONCLUSION}

The analysis of sociodemographic aspects after transplant has revealed a negative influence of advancing age on the domain scores of symptoms of liver disease, sleep and sexual function. The results of mean by gender were homogeneous, with significantly higher values for males in the loneliness domain. Receivers with higher educational level had better scores in the domain of stigma of the disease. Patients with higher incomes had better values in the domains of quality of social interaction and stigma of the disease.

\section{RESUMO}

Objetivo: Verificar a influência dos fatores sociodemográficos na qualidade de vida dos pacientes depois do transplante de fígado.Método: Estudo transversal, com 150 pacientes submetidos ao transplante de fígado em um centro de referência. Aplicou-se um instrumento sociodemográfico e o questionário Liver Disease Quality of Life. Foi realizada Análise de Variância (ANOVA) e comparações múltiplas pelo teste de Tukey e Games-Howell, quando $\mathrm{p}<0,05$. Resultados: A idade avançada apresentou influência nos domínios: sintomas da doença hepática $(p=0,049)$, sono $(p=0,023)$ e função sexual $(p=0,03)$. Os homens apresentaram melhores médias significativas do que as mulheres na dimensão isolamento $(\mathrm{p}=0,037)$. Pacientes com nível de instrução mais alto apresentaram maiores valores no domínio estigma da doença hepática ( $\mathrm{p}=0,014)$. Houve interferência da renda nos domínios qualidade da interação social ( $\mathrm{p}=0,033)$ e estigma da doença $(\mathrm{p}=0,046)$. Conclusão: Em metade dos domínios de qualidade de vida, houve influência de alguma variável sociodemográfica.

\section{DESCRITORES}

Transplante de Fígado; Qualidade de Vida; Avaliação em Saúde; Perfil de Saúde.

\section{RESUMEN}

Objetivo: Verificar la influencia de los factores sociodemográficos en la calidad de vida de los pacientes después del trasplante de hígado. Método: Estudio transversal, con 150 pacientes sometidos al trasplante de hígado en un centro de referencia. Se aplicó un instrumento sociodemográfico y el cuestionario Liver Disease Quality of Life. Se llevó a cabo el Análisis de la Varianza (ANOVA) y comparaciones múltiples mediante la prueba de Tukey y Games-Howell, cuando $\mathrm{p}<0,05$. Resultados: La edad avanzada presentó influencia en los 
dominios: síntomas de la enfermedad hepática $(\mathrm{p}=0,049)$, sueño $(\mathrm{p}=0,023)$ y función sexual $(\mathrm{p}=0,03)$. Los hombres presentaron mejores promedios significativos que las mujeres en la dimensión aislamiento $(\mathrm{p}=0,037)$. Pacientes con nivel de instrucción más alto presentaron mayores valores en el dominio estigma de la enfermedad hepática ( $\mathrm{p}=0,014)$. Hubo interferencia de la renta en los dominios calidad de la interacción social $(\mathrm{p}=0,033)$ y estigma de la enfermedad ( $\mathrm{p}=0,046)$. Conclusión: En la mitad de los dominios de calidad de vida, hubo influencia de alguna variable sociodemográfica.

\section{DESCRIPTORES}

Trasplante de Hígado; Calidad de Vida; Evaluación en Salud; Perfil de Salud.

\section{REFERENCES}

1. Loria A, Escheik C, Gerber NL, Younossi ZM. Quality of life in cirrhosis. Curr Gastroenterol Rep. 2013;15(1):301-7.

2. Mendes KDS, Roza BA, Barbosa SFF, Schirmer J, Galvão CM. Organ and tissue transplantation: responsibilities of nurses. Texto Contexto Enferm [Internet]. 2012 [cited 2015 Oct 20]; 21(4):945-53. Available from: http://dx.doi.org/10.1590/S0104-07072012000400027

3. Associação Brasileira de Transplantes de Órgãos. Dimensionamento dos transplantes no Brasil e em cada estado (2007 - 2014). RBT [Internet]. 2014 [citado 2015 maio 14];20(4):3-Disponível em: http://www.abto.org.br/abtov03/Upload/file/RBT/2014/rbt2014-lib.pdf

4. Saab S, Ng V, Landaverde C, Lee SJ, Comulada WS, Arevalo J, et al. Development of a disease specific questionnaire to measure health related quality of life in liver transplant recipients. Liver Transpl. 2011;17(5):567-79.

5. Orr JG, Homer T, Ternent L, Newton J, McNeil CJ, Hudson M, et al. Health related quality of life in people with advanced chronic liver disease. J Hepatol. 2014; 61(5):1158-65.

6. Gotardo DRM, Strauss E, Teixeira MCD, Machado MCC. Liver transplantation and quality of life: relevance of a specific liver disease questionnaire. Liver Int. 2008;28(1):99-106.

7. Matos MMPC. Impacto da doença e do transplante hepático na qualidade de vida de doentes com cirrose: estudo exploratório. Cad Saúde [Internet]. 2011 [citado 2016 mar. 16];4(1):7-36. Disponível em: http://hdl.handle.net/10400.14/12486

8. Teixeira MCD, Ribeiro MFGS, Strauss E. A new insight into differences among non-cirrhotic and cirrhotic patients using the Liver Disease Quality of Life Instrument (LDQOL). Ann Hepatol. 2005;4(4):264-71.

9. Gralnek IM, Hays RD, Kilbourne A, Rosen HR, Keeffe EB, Artinian L, et al. Development and evaluation of the Liver Disease Quality of Life instrument in persons with advanced, chronic liver disease--the LDQOL 1.0. Am J Gastroenterol. 2000;95(12):3552-65.

10. Guimaro MS, Lacerda SS, Karam CH, Ferraz-Neto BH, Andreoli PBA. Psychosocial profile of patients on the liver transplant list. Transplant Proc. 2008;40(3):782-84.

11. Associação Brasileira de Transplantes de Órgãos. Registro Brasileiro de Transplantes 10 anos: análise qualitativa [Internet]. São Paulo: ABTO; 2007 [citado 2009 jun. 18]. Disponível em: http://www.abto.org.br/abtov03/Upload/file/RBT/RBT_10_Anos/RBT_10Anos_2007.pdf

12. Bryce CL, Angus DC, Arnold RM, Chang C-CH, Farrell MH, Manzarbeitia C, et al. Sociodemographic differences in early access to liver transplantation services. Am J Transplant. 2009;9(9):2092-101.

13. Bryce $\mathrm{CL}$, Chang $\mathrm{C}-\mathrm{CH}$, Angus DC, Arnold RM, Farrell MH, Roberts MS. The effect of race, sex, and insurance status on time-to-listing decisions for liver transplantation. J Transplant. 2010:467976.

14. Stilley CS, DiMartini AF, Tarter RE, DeVera M, Sereika S, Dew MA, et al. Liver transplant recipients: individual, social, and environmental resources. Prog Transplant [Internet]. 2010 [cited 2013 Oct 30];10(1):68-74. Available from: http://www.ncbi.nlm.nih.gov/pmc/articles/ PMC2858345/

15. Instituto Brasileiro de Geografia e Estatística. Síntese de Indicadores Sociais: uma análise das condições de vida da população brasileira [Internet]. Rio de Janeiro: IBGE; 2013 [citado 2014 jan. 15]. Disponível em: http://biblioteca.ibge.gov.br/visualizacao/livros/liv66777.pd

16. Sainz-Barriga M, Baccarani U, Scudeller L, Risaliti A, Toniutto PL, Costa MG, et al. Quality-of-life assessment before and after liver transplantation. Transplant Proc. 2005;37(6):2601-4.

17. Desai R, Jamieson NV, Gimson AE, Watson CJ, Gibbs P, Bradley JA, et al. Quality of Life up to 30 years following liver transplantation. Liver Transpl. 2008;14(10):1473-79.

18. Baere C, Delva D, Kloeck A, Remans K, Vanrenterghem Y, Verleden G, et al. Return to work and social participation: does type of organ transplantation matter? Transplantation. 2010;89(8):1009-15.

19. Rodrigues RTS, Bruscato WL, Horta ALM, Nogueira-Martins LA. Estudo preliminar sobre a qualidade de vida e sintomatologia depressiva de pacientes em fase pré e pós-transplante hepático. Arq Bras Ciênc Saúde [Internet]. 2008 [citado 2012 fev. 10]; 33(2):74-8. Disponível em: http://files.bvs.br/upload/S/1983-2451/2008/v33n2/a74-78.pdf

20. Saab S, Bownik H, Ayoub N, Younossi Z, Durazo F, Han S, et al. Differences in health-related quality of life scores after orthotopic liver transplantation with respect to selected socioeconomic factors. Liver Transpl. 2011;17(5):580-90.

21. Jin S, Yan L, Li B, Wen T, Zhao J, Zeng Y, et al. Quality of life and psychologic distress of recipients after adult Living-Donor Liver Transplantation (LDLT): a study from Mainland China. Transplant Proc. 2010;42(7):2611-6.

22. Cabieses B, Zitko P, Pinedo R, Espinoza M, Albor C. ¿Cómo se ha medido la posición social en investigación en salud?: una revisión de la literatura internacional. Rev Panam Salud Pública. 2011;29(6):457-68.

23. Estraviz B, Quintana JM, Valdivieso A, Bilbao A, Padierna A, Urbina JO, et al. Factors influencing change in health-related quality of life after liver transplantation. Clin Transplant. 2007;21(4):481-90. 
24. Åberg F, Rissanen AM, Sintonen H, Roine RP, Höckerstedt K, Isoniemi H. Health-related quality of life and employment status of liver transplant patients. Liver Transpl. 2009;15(1):64-72.

25. Gruttadauria S, Grosso G, Mistretta A, Pagano D, Scianna G, Vizzini GB, et al. Impact of recipients' socio-economic status on patient and graft survival after liver transplantation: the IsMeTT experience. Dig Liver Dis. 2011;43(11):893-8.

26. Santos AMA, Jacinto PA, Tejada CAO. Causalidade entre renda e saúde: uma análise através da abordagem de dados em painel com os estados do Brasil. Estud Econ. 2012;42(2):229-61.

27. Petrovski BE, Széles G, Melles M, Pataki V, Kardos L, Jenei T, et al. Behaviour does not fully explain the high risk of chronic liver disease in less educated men in Hungary. Eur J Public Health. 2010;21(5):662-6. 